\title{
Cold Plasma as a Potential Activator of Plant Biostimulants
}

\author{
Sławomir Kocira ${ }^{1, * \mathbb{D}}$, María Cecilia Pérez-Pizá ${ }^{2,3}{ }^{\mathbb{D}}$, Andrea Bohata ${ }^{4}$, Petr Bartos ${ }^{4}$ and Agnieszka Szparaga ${ }^{4,5, *}$
}

Citation: Kocira, S.; Pérez-Pizá, M.C.; Bohata, A.; Bartos, P.; Szparaga, A.

Cold Plasma as a Potential Activator of Plant Biostimulants. Sustainability 2022, 14, 495. https://doi.org/ $10.3390 /$ su14010495

Academic Editor: Domenico Ronga

Received: 2 December 2021

Accepted: 30 December 2021

Published: 4 January 2022

Publisher's Note: MDPI stays neutral with regard to jurisdictional claims in published maps and institutional affiliations.

Copyright: (c) 2022 by the authors. Licensee MDPI, Basel, Switzerland. This article is an open access article distributed under the terms and conditions of the Creative Commons Attribution (CC BY) license (https:// creativecommons.org/licenses/by/ $4.0 /)$.
1 Department of Machinery Exploitation and Management of Production Processes, University of Life Sciences in Lublin, Akademicka 13, 20-950 Lublin, Poland

2 Faculty of Agricultural and Veterinary Sciences, Pilar Campus, University of El Salvador, Buenos Aires B1630AHU, Argentina; mariacecilia.perezpiza@usal.edu.ar

3 Faculty of Agronomy, University of Buenos Aires, National Scientific and Technical Research Council, Buenos Aires C1417DSE, Argentina

4 Faculty of Agriculture, University of South Bohemia in České Budějovice, 37005 Ceske Budejovice, Czech Republic; bohata@zf.jcu.cz (A.B.); bartos@zf.jcu.cz (P.B.)

5 Department of Agrobiotechnology, Koszalin University of Technology, 75-620 Koszalin, Poland

* Correspondence: slawomir.kocira@up.lublin.pl (S.K.); agnieszka.szparaga@tu.koszlin.pl (A.S.)

\begin{abstract}
Agriculture has become a sector with a huge impact on the natural environment. The interest of agriculture in the category of innovative bio-stimulants is due to the intensive search for preparations based on natural substances. This is not possible without developing and implementing innovative technologies, e.g., cold plasma, along with innovative technologies supporting farmers. Therefore, given the need to prevent environmental damage caused by intensive agriculture, plant production and protection must be targeted at merging the stimulation of crop growth and the elimination of threats to humans and the environment. The analysis of how cold plasma can influence the production of organic bio-stimulants seems to be an unavoidable step in future approaches to this topic. Since allelopathic plants represent a source of many chemical compounds promoting crop growth and development, the coupling of biologically-active compound extraction with plasma activation of allelopathic extracts has interesting potential in offering the most modern alternative to conventional agriculture. However, its implementation in practice will only be feasible after a comprehensive and thoughtful investigation of the mechanisms behind crops' response to such bio-stimulants.
\end{abstract}

Keywords: sustainable; agricultural production; soybean; stimulation; activation

\section{Introduction}

Over recent years, we have become aware that agriculture has become one of the economic sectors having a huge impact on the natural environment. The significant increase in demand for food and feed, recorded across the globe, seems to put additional pressure on this branch of the economy. Therefore, research into potential novel products stimulating the growth, development, and yield of crops, along with explaining the mechanisms involved, has prompted efforts undertaken to ensure global food security as well as sustainable and optimized agricultural development. However, it bears noting that meeting the growing global demand for agricultural products should minimize the adverse impacts of food production and consumption on the natural environment [1]. This is not possible without developing and implementing innovative technologies supporting farmers. Therefore, given the need to prevent environmental damage caused by intensive agriculture, plant production and protection must be targeted at merging the stimulation of crop growth and the elimination of threats to humans and the environment [2].

However, considering changing climatic conditions and the growing awareness of consumers of plant protection and fertilization and their concerns about genetically modified organisms (GMO), ensuring safe, high-quality agricultural products requires an unconventional approach [3,4]. Many research results indicate that the agrotechnical measures 
applied so far are insufficient, especially under unfavorable conditions. Their poor efficacy causes a drastic reduction in yield and, consequently, lower profitability for agricultural producers. In recent years, bio-stimulants have gained recognition as products supporting physiological processes in plants and promoting their growth and development under optimal and suboptimal conditions [5]. However, despite encouraging research results, it appears that farmers have a limited range of such products available on the market, and that their purchase and use is costly. An additional problem is that popular bio-stimulating products are usually targeted for horticulture and fruit harvesting. There is also concern that commercial products are very rarely recommended for use in the cultivation of highprotein or legume crops (with a lack of information about this group of plants, treatment dates, or recommended doses in various application methods) [6]. Therefore, scientists are working on new-generation bio-stimulants, which would provide a designed and dedicated agronomic tool to meet the demand for alternative methods, based on novel, bioactive, and environmentally friendly substances supporting biodiversity in agricultural ecosystems [4]. According to the latest EU regulation, plant extracts have been recognized as a valuable group of such bio-stimulants. Therefore, they can be a suitable substitute for synthetic plant growth regulators. According to the new EU regulation [7], products based on allelochemicals can be classified as natural bio-stimulants, i.e., a group of products (other than fertilizers) that stimulate plant growth when used in small amounts. These ecosystem-friendly, natural formulations promote growth, mineral uptake, and plant tolerance to abiotic stresses [8]. Thus, the main goal of allelopathy research is to initially observe allelopathic effects and then apply them in agricultural production. Only such an approach will make it possible to reduce or eliminate the share of agricultural chemicals and allow for the practical application of methods ensuring the sustainable development of agricultural production and ecological systems $[9,10]$.

However, modern agriculture, dependent on pesticides and fertilizers, is looking for new methods of increasing crop growth with the least possible environmental impact. In addition to bio-stimulants, one promising option is the use of cold plasma. Plasma discharges are widely used in many industries and sciences including surface sterilization [11,12], decontamination [13], bacterial inactivation [14], and removal of contaminants from water [15,16] in biomedicine and many interdisciplinary fields [17]. Over recent years, there has also been an increasing interest in cold plasma in agriculture, such as seed treatment for removal of surface contamination, or germination stimulation $[16,18,19]$. This technology is considered a tool to support agriculture towards a change in farming towards organic systems. Plasma activation of bio-stimulants may also be an answer to the problems of modern agriculture, related to changes in European strategies. The European "Farm to Fork Strategy" calls for a 50\% reduction in the use of chemical pesticides, a reduction in nutrient losses of at least $50 \%$, and a reduction in fertilizer use of at least $20 \%$ by 2030 . In addition, a plan to bring $25 \%$ of agricultural land under organic cultivation is fundamental. On this path to agricultural change, it seems that genetic improvements and improved varieties will be insufficient, and the key to achieving these goals, will be plasma-activated biostimulants [20]. Application of such bio-stimulants seems to be a convenient solution, combining the effects of promoting plant growth and development with environmental protection. However, no experiments with the application of activated bio-stimulants to crop plants have been conducted, and the potential of cold plasma itself, although great, seems to be poorly explored in agricultural applications [21].

Therefore, the analysis of its influence on the production of organic bio-stimulants seems to be a future approach. Due to the fact that allelopathic plants represent a source of many chemical compounds promoting crop growth and development, the coupling of biologically active compounds extraction with plasma activation of the obtained extracts may offer the most modern alternative to conventional agriculture. However, its implementation in practice will only be feasible after thorough investigation of the mechanisms behind crops' response to such bio-stimulants. 
If the combined efforts of scientists in the fields of plasma physics and chemistry and agronomy and plant physiology are successful, the use of plasma-activated bio-stimulants could have a measurable impact on addressing the environmental, economic, and social challenges of feeding a growing population in a sustainable and responsible manner under a changing climate [22].

The aim of this article is to present the state of the art in the possibilities of producing natural bio-stimulants based on extracts of allelopathic plants in the context of their further activation with cold plasma (Figure 1). Cold plasma technology can be a tool in the designing and production of a new generation of bio-stimulants, effectively supporting the growth and development of plants and their yielding potential. To our best knowledge, this is the first article on the possibilities of using cold plasma for bio-stimulant activation.

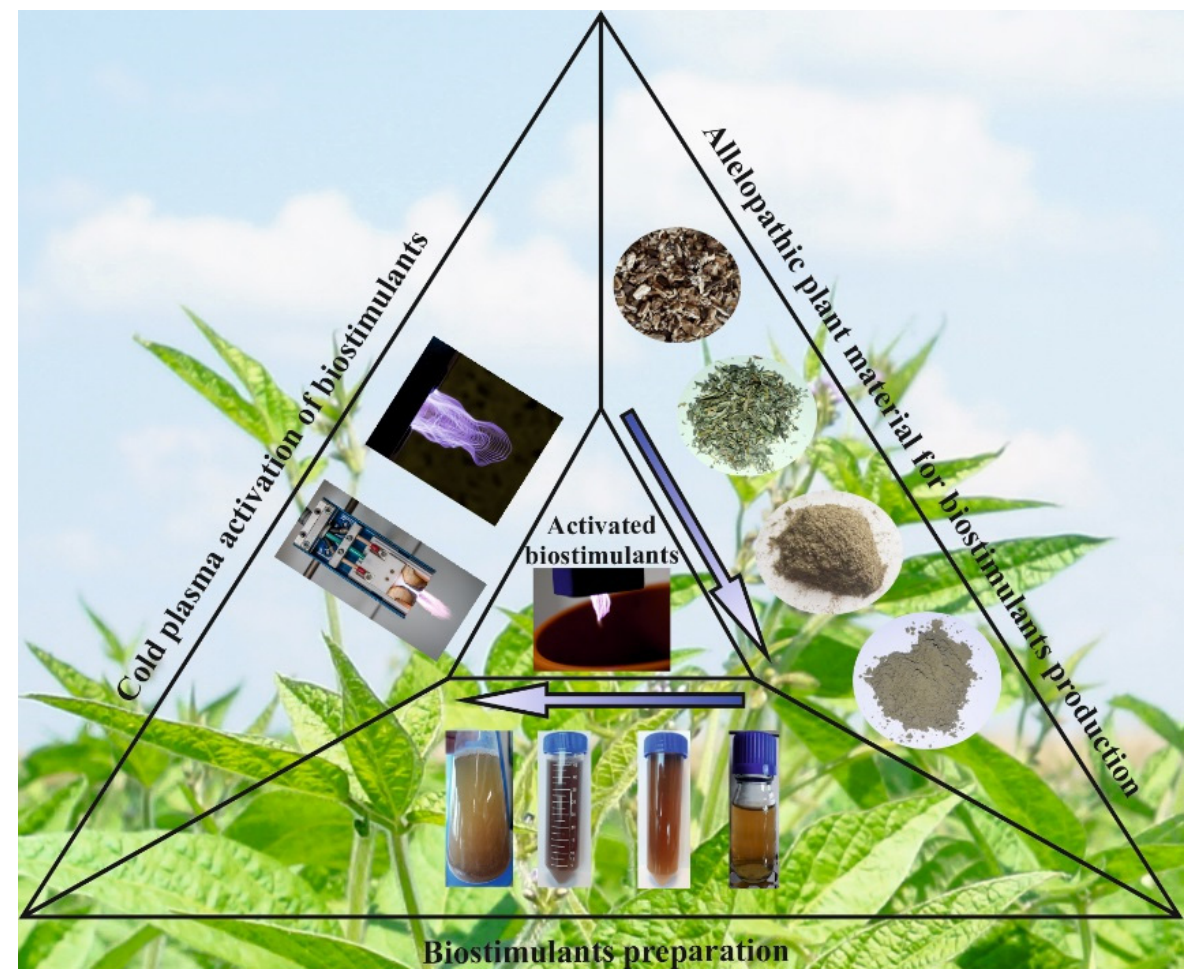

Figure 1. Plasma activation of allelopathic biostimulants.

\section{Plants as a Material for the Production of Bio-Stimulants}

The search for sources of novel preparations, based on the rich experience of folk medicine and the principles of allelopathy, seems to be the right direction. By learning about the interactions of certain plants with others and their antimicrobial activity, one can search for raw materials that would become ideal candidates for the development of a new bio-stimulant. This is due to the fact that the chemical compounds present in such plant bio-stimulants naturally occur in all higher plants, though in various concentrations and combinations [23]. Groups of medicinal or allelopathic plants are core elements of not only traditional medicine or pharmacology, but - in many cases-also of organic agriculture. Thus, recognizing their value and importance as a potential source of novel compounds of agronomic value [24], the first strategies have been developed to support plant growth under stress conditions. So far, respective investigations have been conducted with plant extracts from Moringa oleifera leaves, corn kernels, and licorice roots [25-28], plant-derived protein hydrolysate, lemongrass and garlic extract $[29,30]$. The results of studies by Cheema et al. [31] and Farooq et al. [32] showed that water extracts obtained from sorghum, cabbage, sunflower, rice, wheat, barley, and moringa, containing specific allelochemicals, improved the growth of various crops. These authors mutually agreed that the role of plant extracts and their bioactive compounds might be due to their direct and indirect influence on physi- 
ological processes in crops. However, it should be emphasized that allelopathic interactions are currently included in the group of biotic stresses. According to Lichtenthaler [33], stress signaling in plants, and their response to stress factors, vary and are associated with various forms of signal reception and transduction in the plant and its organs, which will consequently lead to direct metabolic response and the enhanced expression of genes responsible for the activation of enzymes as well as the synthesis of proteins, metabolites, or hormones [34]. This proves that they can be used to stimulate growth and, therefore, can replace synthetic growth regulators [32]. The use of plant extracts, which have a bio-stimulating effect on plants, can be one of the measures to increase the productivity of crops. Botanical extracts from allelopathic plants, like other natural bio-stimulants, show positive effects on crops due to the fact that they are extremely rich in bioactive compounds. Their active compounds act at different metabolic levels, which promotes better absorption, transport, and utilization of nutrients [35]. It should be emphasized that the extracts obtained can offer an alternative not only to commercial bio-stimulants, but also to the extracts obtained from tropical plants [36]. The bio-stimulating effect of allelopathic extracts is directly related to the total content of phenols and flavonoids [37]. These secondary metabolites are the main allelochemicals found in plants with documented allelopathic and bio-stimulating activity. The phenolic compounds at low concentrations are referred to as plant germination and growth stimulants, because they are able to act as antioxidants and protect plants against reactive oxygen species, or as plant growth, soil processes, and nutrient metabolism regulators [35,38]. Additionally, the stimulatory properties of allelopathic extracts are also associated with the presence of amino acids, plant hormones, and micro- and macro-nutrients [39-41].

However, despite these encouraging results, the mechanisms behind a possible positive effect of organic bio-stimulants remain unknown. The identification of plant responses at different levels and the linking of these to appropriate metabolic pathways will facilitate the design and development of second-generation bio-stimulating products (bio-stimulant 2.0) in the future, making agriculture more sustainable and resilient [42]. Although allelopathy is known as an ecological phenomenon, there is still little evidence of its possible use in agriculture. Previous studies on the use of water extracts of Artemisia absinthium L., Levisticum officinale Koch., Verbascum thapsiform L., and Arctium lappa L. in three-year soybean cultivation showed that they influenced plant physiology by improving biometric characteristics. Additionally, their application significantly increased the soybean yield as compared to the control samples. The most important conclusion from these studies was that the extracts elicited their bio-stimulating effect by modifying the basic biochemical indicators of soybeans. Thus, the first results of the research have shown that the use of bio-stimulants in the form of extracts from medicinal plants represents an agronomic practice based on an environmentally friendly approach to the possibility of combining the principles of allelopathy and the action of bio-stimulants. Artemisia absinthium as well as Levisticum officinalle, Linum usitatissimum and Arctium lappa, i.e., plants considered as a kind of a platform or a matrix for the development of innovative bioproducts $[6,39,43,44]$, were selected in the search for new plant species with a putative bio-stimulating potential. Earlier research conducted by our group have shown that water extracts obtained from these plants effectively increased the germination capacity and seedling emergence, as well as reduced the contamination of white mustard seeds; white cabbage; yellow lupine; pea; fodder, sugar and red beet; winter rape, winter agrimony, and also spring barley, by fungi and bacteria. The observed positive responses of seeds and seedlings to the allelopathic extracts prompted us to undertake efforts to design a novel bio-stimulant for crops that would have no residual or toxic effects on the natural environment [45-49]. In addition, recognizing and specifying the mechanisms of their action will, in the future, establish the optimal doses, methods, and dates of their application in field conditions. The use of such bioproducts would also contribute to protecting the natural environment by favoring the maintenance of biodiversity and supporting the increase in the population of invertebrates, including pollinators and other beneficial insects, which are natural allies in the fight 
against pests [50]. The designed preparations will have no harmful or toxic effects on these insects. This approach to providing effective methods for the sustainable development of agricultural production and ecological biosystems [9,51-54] is in line with the current assumptions of the EU's 2030 biodiversity strategy.

The results of the little research conducted in this respect indicate that the morphological parts of higher plants (including seeds, leaves or roots) from the Amaryllidaceae, Brassicacae, Ericaceae, Fabaceae, Fagaceae, Moringaceae, Plantaginaceae, Poaceae, Rosaceae, Solanaceae, Theaceae, and Vitaceae families may serve as the raw material for the production of bio-stimulants [6,55-62]. The therapeutic, but also agronomic, potential of allelopathic plant extracts is directly related to the total content of phenolics and flavonoids [37]. These compounds, also called secondary metabolites, are the main allelochemical substances found in plants with documented allelopathic activity [63]. In the literature on the subject, phenolic compounds in low concentrations are referred to as plant germination and growth promoters $[64,65]$ due to their capability to act as antioxidants, i.e., serve as effective regulators of plant growth rate, soil processes, or nutrient metabolism [35]. However, the production of a novel type of bio-stimulant from them requires a systematic approach to design and use. Such a comprehensive process must begin with specifying the raw materials, followed by defining extraction methods, and end in product development, allowing effective transformation of natural ingredients with a potential biological activity into high-quality bio-stimulants. With this approach, it is also possible to predict the function of natural compounds and how they modulate plant physiology, making them more resistant to environmental stresses [2].

\section{The Use of Cold Plasma in Agriculture}

Like bio-stimulants, atmospheric cold plasma has attracted the attention of plant physiologists for several years due to its potential to increase plant growth and tolerance to biotic and abiotic stresses [66-69]. Cold plasmas are partially ionized gases composed of UV photons and highly reactive species of nitrogen, oxygen, and hydrogen (RNS, ROS, and RHS), among other compounds [69]. This technology is considered an environmentally friendly method for improving crop production [68]. Previous investigations conducted by our research group have shown that plasma discharge coupled with the coating of Metarhizium anisopliae and Trichoderma virens seeds offers an alternative to chemical seed dressing. The results of these studies have proved that the application of both plasma technology and the combination of plasma and seed bio-treatment foster a great potential in seed production technology as value-added processes. Laboratory analyses and field experiments have demonstrated that cold plasma applied to seeds can stimulate the germination and early growth of spring barley, winter rape, and spring poppy seeds, while also having a positive effect on plants' yield [70]. Therefore, these investigations have prompted us to assess the feasibility of using plasma technology to activate organic bio-stimulants that would improve crop growth and development. This would represent a cheaper and simpler alternative to time-consuming seed dressing. Research by other authors has shown that plasma-activated liquids, including water, reveal properties supporting plant growth and development. This is so because the action of plasma modifies the chemical properties of liquids, transforming them into mixtures of reactive oxygen and nitrogen species (RONS), including $\mathrm{H}_{2} \mathrm{O}_{2}$ and $\mathrm{NO}$ biomolecules, considered as signaling elements in various processes of cellular metabolism and as elements regulating plant responses to various stresses [14,22,71,72]. Therefore, based on the fact that one of the key plant nutrition strategies is foliar and soil application of nutrients or fertilizers (commonly used in water solutions), as well as using the latest knowledge in the field of plasma agriculture development, it becomes justified to combine two environmentally friendly strategies, i.e., the use of bio-stimulants and plasma activation of liquids. The application of plasma-activated bio-stimulants seems to be the optimal system, merging the effects of plant nutrition and protection. However, this will not be possible or effective without understanding the mechanisms underlying plant responses to such treatment. Based on 
the results of research by other authors, we can assume that the chemical composition and activity of bio-stimulants may also depend on plasma technology. This hypothesis is based on the fact that the chemical composition of plasma-activated water differs from that of ordinary water. However, no experiments have been performed so far with soil application of plasma-activated allelopathic bio-stimulants, and no effect of this treatment on plant growth has ever been observed. There is also a lack of information about the metabolic pathways activated in these agronomic processes [17].

\section{Cold Plasma in Field Crops: Benefits from Germination to Harvest in Soybean}

Recent experiments employing cold plasma generated by dielectric barrier discharges (DBD) to treat soybean seeds demonstrated that it could effectively remove seed-borne fungal pathogens, thus enhancing seed health and positively impacting germination parameters (Figure 2A) [67]. The deleterious effect of cold plasma on fungal pathogens was verified through the direct treatment of fungal colonies growing in vitro, which showed significantly less growth, mycelial mass and sporulation than the non-treated colonies [73]. Additional experiments were performed using healthy soybean seeds to elucidate the precise mechanisms of cold plasma on germination unrelated to pathogen control [74]. It was shown that plasma could stimulate water absorption during germination by physically and biochemically modifying the seed coat's structure through the action of its active compounds (ROS and RNS). It was suggested that this plasma's active compounds could also work as signal molecules in regulating phytohormones related to germination (abscisic acid, ABA, indoleacetic acid, AIA, and ethylene), and participate in the regulation of antioxidant enzymatic activities (Figure 2A) [74]. In a subsequent study, soybean seeds were exposed to plasma and then inoculated with Bradyrrhizobium sp., resulting in enhanced plant nodulation traits compared to controls (non-treated with plasma) (Figure 2B) [75]. Root growth promotion was also observed, and plasma's active compounds were suggested to be involved in this effect by promoting expansin's gene expression. These results highlighted the synergy between plasma and the inoculant, possibly due to plasma-produced modifications on the seed coat. Recent results showed that plants grown from cold plasma-treated seeds presented differential phenotype and DNA methylation patterns at different stages of growth, showing the possible involvement of epigenetic modifications on cold plasma effects on seeds and plants [76]. Cold plasma appears to be a promising technology to treat seeds at a large scale for field-grown crops like soybean, as it was proven to enhance the yield of plants significantly [74].

(A) Cold plasma increases germination and early growth. After seed exposition to plasma treatment, germination and seedling growth are enhanced compared to non-treated seeds (control). These effects are related to reductions in the percentage of seeds infected with fungi, changes in the physical/biochemical properties of the seedcoats (higher hydrophilicity), modifications on antioxidant and phytohormones (ethylene, $\mathrm{C}_{2} \mathrm{H}_{4}$, indoleacetic acid, IAA, and abscisic acid, ABA) profiles, all orchestrated by plasma's active species (reactive oxygen species, ROS, and reactive nitrogen species, RNS).

(B) Cold plasma applied to seeds has positive effects on plant growth and yield. Plasma promotes early root growth, thus stimulating nodulation. The improvement in nodulation determines increases in the biological nitrogen fixation (BNF), which contribute to plant growth in the more advanced stages and, consequently, enhance plant yield. 
A)

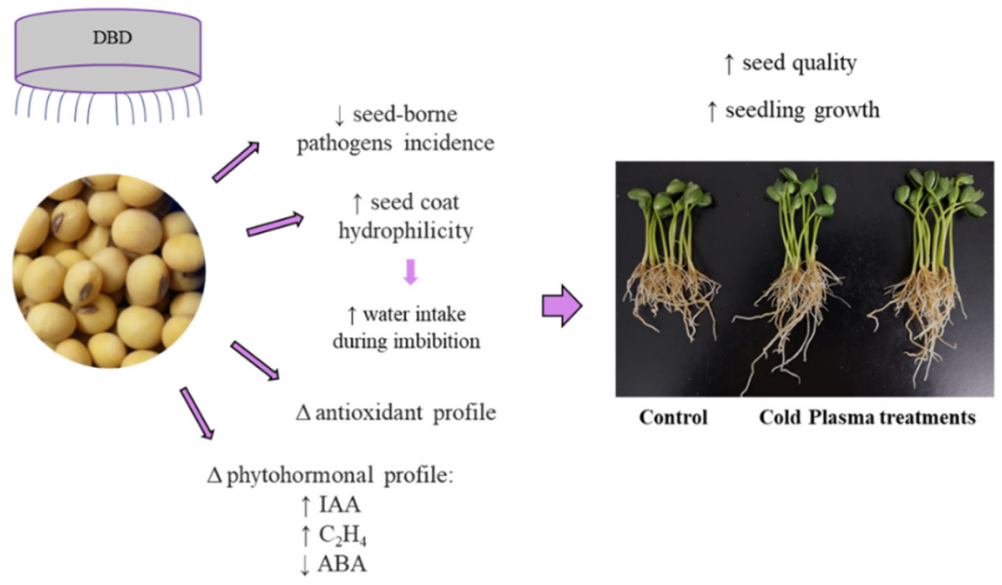

B)

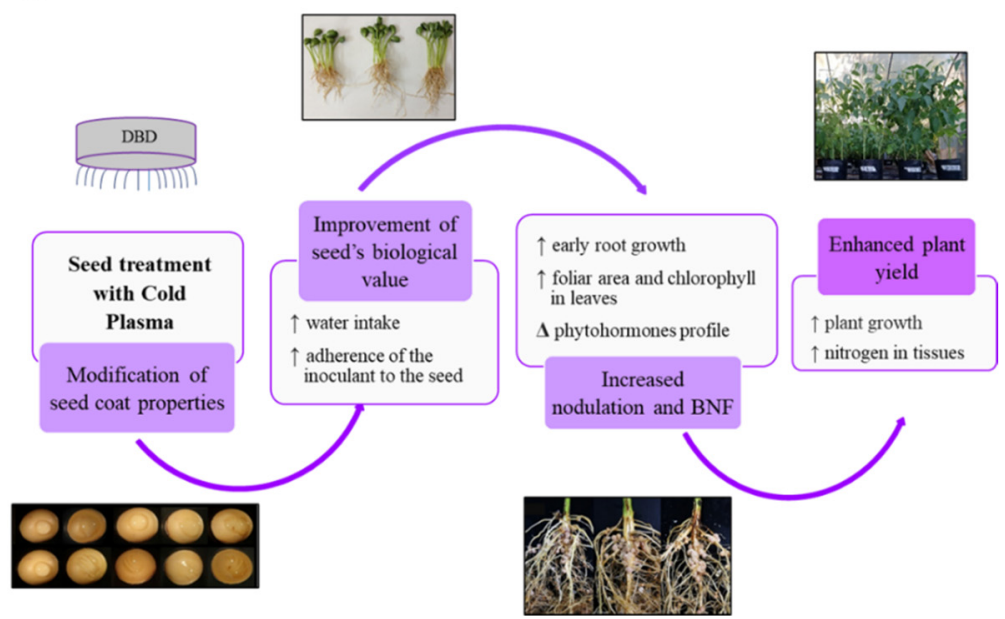

Figure 2. Effects of cold plasma treatments on soybean seed quality, plant growth and yield using Dielectric Barrier Discharges (DBD) and combining different types of dielectric barriers, transport gases and exposure times. (A) Cold plasma increases germination and early growth. (B) Cold plasma applied to seeds has positive effects on plant growth and yield (adapted from Pérez-Pizá [77]).

\section{Activation of Liquids with Cold Plasma}

Based on the latest literature reports, it is already known that cold plasma can be used for liquid treatment (also called liquid activation), which in turn leads to complex chemical mechanisms that are still being explored. In addition, the use of plasma technology may be associated with the generation of a transient electric field and with a change in the flow kinetics and thermal effects, which may directly determine the chemical mechanisms observed in the liquid. These interactions between liquids and plasma are widely exploited today. Plasma has been used to treat water by removing pesticides [78] or pharmaceuticals [79]. It has also found application in direct "bubbles" generation in water, allowing inactivation of the growth and development of E. coli bacteria [80]. Despite the fact that plasma activation of liquids is widely used in biomedicine (cancer treatment) [81-83], and in microbiology and disinfection processes (inactivation of bacteria and fungi) [84-86], there is still little research into this technology for agricultural applications. The potential of plasma-activated liquids seems enormous but is yet untapped. Few research results indicate that plasma-activated water improves seed germination and elongates seedling stems in such plants as lentils, radishes, tomatoes or sweet peppers [87-89]. Given that, the use of plasma technology in agriculture can bring many additional benefits to increase crop production [21]. However, apart from the results demonstrating the potential of 
plasma-activated water in the irrigation of crop seeds, no other possible directions for using this technology in agronomic applications have been identified.

Therefore, the analysis of its influence on the produced organic bio-stimulants seems to be an approach for the future. Due to the fact that allelopathic plants represent a source of many chemical compounds promoting crop growth and development, the coupling of biologically-active compounds extraction with plasma activation of the obtained extracts may offer the most modern alternative to conventional agriculture. However, its implementation in practice will only be feasible after thorough investigation of the mechanisms behind crops response to such bio-stimulants. In addition, given that the organic bio-stimulants produced are environmentally friendly by definition, it was decided that the plasma-activated preparations will be administered via application to soil. Based on the literature data, it was assumed that the soil application of plasma-activated water does not cause soil acidification. The research by Šimečková et al. [90] demonstrated that the soil $\mathrm{pH}$ remained in the neutral range, even after the application of multiple doses of plasma-activated water, and that, therefore, the soil still offered optimal conditions for plant cultivation [90]. This method of bio-stimulant application will allow not only the full characterization of the response of soybean plants, but will not have an adverse impact on the physicochemical properties of the soil. Thus, the results of the research will demonstrate whether obtaining extracts from allelopathic plants subjected to plasma activation will trigger a response in soybean plants, leading to an increase in crop productivity, and thus indicate whether this approach to sustainable agriculture will allow the development of commercial products for improving crop yield in the future, posing no threat to the natural environment.

\section{Conclusions}

The analysis of how cold plasma can influence the production of organic bio-stimulants seems to be an unavoidable step for future approaches to this topic. Since allelopathic plants represent a source of many chemical compounds promoting crop growth and development, the coupling of biologically-active compound extraction with plasma activation of the obtained extracts has interesting potential in offering the most modern alternative to conventional agriculture. However, its implementation in practice will only be feasible after a comprehensive and thoughtful investigation of the mechanisms behind crops response to such bio-stimulants.

Author Contributions: Conceptualization, S.K., M.C.P.-P., A.B., P.B. and A.S.; validation, S.K., M.C.P.-P., A.B., P.B. and A.S.; writing-original draft preparation, S.K., M.C.P.-P., A.B., P.B. and A.S.; writing-review and editing, S.K., M.C.P.-P., A.B., P.B. and A.S.; visualization, S.K., M.C.P.-P. and A.S.; funding acquisition, S.K. All authors have read and agreed to the published version of the manuscript.

Funding: The APC was funded from the "Excellent science" program of the Ministry of Education and Science as a part of the contract no. DNK/SP/465641/2020 "The role of the agricultural engineering and environmental engineering in the sustainable agriculture development".

Institutional Review Board Statement: Not applicable.

Data Availability Statement: Not applicable.

Conflicts of Interest: The authors declare no conflict of interest.

\section{References}

1. Paul, K.; Sorrentino, M.; Lucini, L.; Rouphael, Y.; Cardarelli, M.; Bonini, P.; Reynaud, H.; Canaguier, R.; Trtílek, M.; Panzarová, K.; et al. Understanding the biostimulant action of vegetal-derived protein hydrolysates by high-throughput plant phenotyping and metabolomics: A case study on tomato. Front Plant Sci. 2019, 10, 47. [CrossRef]

2. Du Jardin, P.; Xu, L.; Geelen, D. Agricultural Functions and Action Mechanisms of Plant Biostimulants (PBs): An Introduction. In The Chemical Biology of Plant Biostimulants, 1st ed.; Geelen, D., Xu, L., Eds.; Wiley: Hoboken, NJ, USA, 2020; pp. 3-30.

3. Posmyk, M.M.; Szafrańska, K. Biostimulators: A new trend towards solving an old problem. Front. Plant Sci. 2016, 7, 748. [CrossRef] 
4. Koo, A.J. Metabolism of the plant hormone jasmonate: A sentinel for tissue damage and master regulator of stress response. Phytochem. Rev. 2018, 17, 51-80. [CrossRef]

5. Del Buono, D.; Bartucca, M.L.; Ballerini, E.; Senizza, B.; Lucini, L.; Trevisan, M. Physiological and Biochemical Effects of an Aqueous Extract of Lemna minor L. as a Potential Biostimulant for Maize. J. Plant Growth Regul. 2021. [CrossRef]

6. Szparaga, A.; Kocira, S.; Kapusta, I.; Zaguła, G. Prototyping extracts from Artemisia absinthium L. for their biostimulating properties yield-enhancing, and farmer income-increasing properties. Ind. Crops Prod. 2021, 160, 113125. [CrossRef]

7. Regulation (EU) 2019/1009 of the European Parliament and of the Council of 5 June 2019. Available online: https:/ / eur-lex europa.eu/eli/reg/2019/1009/oj (accessed on 25 November 2021).

8. Hwang, K.S.; Kim, Y.K.; Park, K.W.; Kim, Y.T. Piperolein B and piperchabamide D isolated from black pepper (Piper nigrum L.) as larvicidal compounds against the diamondback moth (Plutella xylostella). Pest Manag. Sci. 2017, 73, 1564-1567. [CrossRef]

9. Jabran, K.; Mahajan, G.; Sardana, V.; Chauhan, B.S. Allelopathy for weed control in agricultural systems. Crops Prot. 2015, 72, 57-65. [CrossRef]

10. Cheng, F.; Cheng, Z. Research progress on the use of plant allelopathy in agriculture and the physiological and ecological mechanisms of allelopathy. Front. Plant Sci. 2015, 6, 1020. [CrossRef]

11. Leipold, F.; Kusano, Y.; Hansen, F.; Jacobsen, T. Decontamination of a rotating cutting tool during operation by means of atmospheric pressure plasmas. Food Control 2010, 21, 1194-1198. [CrossRef]

12. Scholtz, V.; Pazlarova, J.; Souskova, H.; Khun, J.; Julak, J. Nonthermal plasma-A tool for decontamination and disinfection. Biotechnol. Adv. 2015, 33, 1108-1119. [CrossRef]

13. Leipold, F.; Schultz-Jensen, N.; Kusano, Y.; Bindslev, H.; Jacobsen, T. Decontamination of objects in a sealed container by means of atmospheric pressure plasmas. Food Control 2011, 22, 1296-1301. [CrossRef]

14. Bourke, P.; Ziuzina, D.; Boehm, D.; Cullen, P.J.; Keener, K. The Potential of Cold Plasma for Safe and Sustainable Food Production. Trends Biotechnol. 2018, 36, 615-626. [CrossRef]

15. Laroussi, M.; Dobbs, F.C.; Wei, Z.; Doblin, M.A.; Ball, L.G.; Moreira, K.R.; Dyer, F.F.; Richardson, J.P. Decontamination of water by excimer UV radiation. IEEE Plasma Sci. 2002, 30, 1501-1503. [CrossRef]

16. Kriz, P.; Olsan, P.; Havelka, Z.; Bohata, A.; Krishna, S.; Cerny, P.; Filip, M.; Bartos, P.; Kocira, S.; Spatenka, P. Experimental Investigation into the Influence of Plasma Technology on Seed Surface Wettability. Appl. Sci. 2021, 11, 9994. [CrossRef]

17. Škarpa, P.; Klofáč, D.; Krčma, F.; Šimečková, J.; Kozáková, Z. Effect of Plasma Activated Water Foliar Application on Selected Growth Parameters of Maize (Zea mays L.). Water 2020, 12, 3545. [CrossRef]

18. Puač, N.; Gherardi, M.; Shiratani, M. Plasma agriculture: A rapidly emerging field. Plasma Process. Polym. 2018, 15, e1700174. [CrossRef]

19. Randeniya, L.K.; de Groot, G.J.J.B. Non-thermal plasma treatment of agricultural seeds for stimulation of germination, removal of surface contamination and other benefits: A review: Non-thermal plasma treatment of agricultural seeds. Plasma Process. Polym. 2015, 12, 608-623. [CrossRef]

20. Bruins, M.A. Closer Look into the World of Biostimulants. Available online: https://european-seed.com/2021/09/a-closer-lookinto-the-world-of-biostimulants / (accessed on 21 December 2021).

21. Judée, F.; Simon, S.; Bailly, C.; Dufour, T. Plasma-activation of tap water using DBD for agronomy applications: Identification and quantification of long lifetime chemical species and production/consumption mechanisms. Water Res. 2018, 133, 47-59. [CrossRef]

22. Graves, D.B.; Bakken, L.B.; Jensen, M.B.; Ingels, R. Plasma Activated Organic Fertilizer. Plasma Chem. Plasma Process. 2019, 39, 1-19. [CrossRef]

23. Zulfiqar, F.; Casadesús, A.; Brockman, H.; Munné-Bosch, S. An overview of plant-based natural biostimulants for sustainable horticulture with a particular focus on moringa leaf extracts. Plant Sci. 2019, 295, 110194. [CrossRef]

24. Al-Bayati, F.A. Antibacterial Activity of Linum usitatissimum L. Seeds and Active Compound Detection. Rafidain J. Sci. 2007, 18, 27-36. [CrossRef]

25. Rady, M.M.; Desoky, E.S.M.; Elrys, A.S.; Boghdady, M.S. Can licorice root extract be used as an effective natural biostimulant for salt-stressed common bean plants? S. Afr. J. Bot. 2019, 121, 294-305. [CrossRef]

26. Taha, R.S.; Alharby, H.F.; Bamagoos, A.A.; Medani, R.A.; Rady, M.M. Elevating tolerance of drought stress in Ocimum basilicum using pollen grains extract; a natural biostimulant by regulation of plant performance and antioxidant defense system. S. Afr. J. Bot. 2020, 128, 42-53. [CrossRef]

27. Desoky, E.M.; Merwad, A.M.; Rady, M.M. Natural biostimulants improve saline soil characteristics and salt stressed-sorghum performance. Commun. Soil Sci. Plant Anal. 2018, 49, 967-983. [CrossRef]

28. ur Rehman, H.; Alharby, H.F.; Alzahrani, Y.; Rady, M.M. Magnesium and Organic Biostimulant Integrative Application Induces Physiological and Biochemical Changes in Sun Flower Plants and Its Harvested Progeny on Sandy Soil. Plant Physiol. Biochem. 2018, 126, 97-105. [CrossRef]

29. Rouphael, Y.; Giordano, M.; Cardarelli, M.; Cozzolino, E.; Mori, M.; Kyriacou, M.C.; Bonini, P.; Colla, G. Plant-and seaweedbased extracts increase yield but differentially modulate nutritional quality of greenhouse spinach through biostimulant action. Agronomy 2018, 8, 126. [CrossRef] 
30. Hayat, S.; Ahmad, H.; Ali, M.; Hayat, K.; Khan, M.A.; Cheng, Z. Cheng Aqueous garlic extract as a plant biostimulant enhances physiology, improves crop quality and metabolite abundance, and primes the defense responses of receiver plants. Appl. Sci. 2018, 8, 1505. [CrossRef]

31. Cheema, Z.A.; Farooq, M.; Khaliq, A. Application of allelopathy in crop production: Success story from Pakistan. In Allelopathy; Cheema, Z., Farooq, M., Wahid, A., Eds.; Springer: Berlin, Germany, 2012; pp. 113-143. [CrossRef]

32. Farooq, M.; Bajwa, A.A.; Cheema, S.A.; Cheema, Z.A. Application of allelopathy in crop production. Int. J. Agric. Biol. 2013, 15, 1367-1378.

33. Lichtenthaler, H.K. The stress concept in plants: An introduction. Ann. N. Y. Acad. Sci. 1998, 851, 187-198. [CrossRef]

34. Pedrol, N.; González, L.; Reigosa, M.J. Allelopathy and abiotic stress. In Allelopathy: A Physiological Process with Ecological Implications; Reigosa, M.J., Pedrol, N., González, L., Eds.; Springer: Dordrecht, The Netherlands, 2006; pp. 171-209.

35. Ertani, A.; Pizzeghello, D.; Francioso, O.; Tinti, A.; Nardi, S. Biological Activity of Vegetal Extracts Containing Phenols on Plant Metabolism. Molecules 2016, 21, 205. [CrossRef]

36. Korzeniowska, K.; Żmudzki, S.; Ambroziak, K.; Wieczorek, P.P. Use of plant extracts containing phenolic compounds in organic agriculture. Przem. Chem. 2017, 96, 1518-1522. [CrossRef]

37. Singh, R.; Verma, P.K.; Singh, G. Total phenolic, flavonoids and tannin contents in different extracts of Artemisia absinthium. J. Complement Med. Res. 2012, 1, 101-104. [CrossRef]

38. Kocira, S.; Czerwińska, E.; Szparaga, A. Analysis of the Ecological Method of Treatment in the Aspect of Increasing the Vitality and Healthiness of Spring Barley Grains Hordeum vulgare L. Rocz. Ochr. Sr. 2018, 20, 1746-1763.

39. Szparaga, A.; Kocira, S.; Findura, P.; Kapusta, I.; Zaguła, G.; Świeca, M. Uncovering the multi-level response of Glycine max L. to the application of allelopathic biostimulant from Levisticum officinale Koch. Sci. Rep. 2021, 11, 15360. [CrossRef]

40. Carvalho, R.S.; Silva, M.A.D.; Borges, M.T.M.R.; Forti, V.A. Plant extracts in agriculture and their applications in the treatment of seeds. Ciência Rural 2022, 52, e20210245. [CrossRef]

41. Mrid, R.B.; Benmrid, B.; Hafsa, J.; Boukcim, H.; Sobeh, M.; Yasri, A. Secondary metabolites as biostimulant and bioprotectant agents: A review. Sci. Total Environ. 2021, 777, 146204. [CrossRef]

42. Rouphael, Y.; Colla, G. Synergistic Biostimulatory Action: Designing the Next Generation of Plant Biostimulants for Sustainable Agriculture. Front. Plant Sci. 2018, 9, 1655. [CrossRef]

43. Szparaga, A.; Kocira, S.; Kapusta, I. Identification of a Biostimulating Potential of an Organic Biomaterial Based on the Botanical Extract from Arctium lappa L. Roots. Materials 2021, 14, 4920. [CrossRef]

44. Kocira, S.; Szparaga, A.; Krawczuk, A.; Bartoš, P.; Zaguła, G.; Plawgo, M.; Černý, P. Plant Material as a Novel Tool in Designing and Formulating Modern Biostimulants-Analysis of Botanical Extract from Linum usitatissimum L. Materials 2021, $14,6661$. [CrossRef]

45. Kocira, S.; Hara, P.; Szparaga, A.; Czerwińska, E.; Beloev, H.; Findura, P.; Bajus, P. Evaluation of the Effectiveness of the Use of Biopreparations as Seed Dressings. Agriculture 2020, 10, 90. [CrossRef]

46. Krawczuk, A.; Parafiniuk, S.; Przywara, A.; Huyghebaert, B.; Rabier, F.; Limbourg, Q.; Mostade, O.; Kocira, S. Technical Parameters of Biostimulant Spraying a Determinant of Biometric Traits and Yield of Soybean Seeds. Agric. Eng. 2021, 25, 171-179. [CrossRef]

47. Szparaga, A.; Czerwińska, E.; Piskier, T. The effect of treating the seeds of Brassica oleracea L. with aqueous extracts on the germination capacity and seed healthiness. J. Res. Appl. Agric. Eng. 2017, 62, 162-167.

48. Czerwińska, E.; Szparaga, A. The vitality and healthiness of oil seeds treated by plant extracts. Acta Sci. Pol. Tech. Agrar. 2015, 14, 47-59.

49. Czerwińska, E.; Szparaga, A.; Deszcz, E. Estimation of effect of dressing in plant extracts on germination capacity of beetroots seeds. Zesz. Nauk. Uniw. Przyr. Wrocławiu-Rol. 2015, 611, 7-20.

50. Sherwood, J. The significance of biomass in a circular economy. Bioresour. Technol. 2020, 300, 122755. [CrossRef] [PubMed]

51. Macías, F.A.; Marín, D.; Oliveros-Bastidas, A.; Varela, R.M.; Simonet, A.M.; Carrera, C.; Molinillo, J.M. Allelopathy as a new strategy for sustainable ecosystems development. Biol. Sci. Space 2003, 17, 18-23. [CrossRef]

52. Li, Z.H.; Wang, Q.; Ruan, X.; Pan, C.D.; Jiang, D.A. Phenolics and plant allelopathy. Molecules 2010, 15, 8933-8952. [CrossRef] [PubMed]

53. Han, X.; Cheng, Z.H.; Meng, H.W.; Yang, X.L.; Ahmad, I. Allelopathic effect of decomposed garlic (Allium Sativum L.) stalk on lettuce (L. sativa Var. Crispa L.). Pak. J. Bot. 2013, 45, 225-233.

54. Bhadoria, P.B.S. Allelopathy: A natural way towards weed management. Amer. J. Exp. Agric. 2011, 1, 7-20. [CrossRef]

55. Yakhin, O.I.; Lubyanov, A.A.; Yakhin, I.A.; Brown, P.H. Biostimulants in Plant Science: A Global Perspective. Front. Plant Sci. 2017, 7, 2049. [CrossRef]

56. Parrado, J.; Bautista, J.; Romero, E.J.; García-Martínez, A.M.; Friaza, V.; Tejada, M. Production of a carob enzymatic extract: Potential use as a biofertilizer. Bioresour. Technol. 2008, 99, 2312-2318. [CrossRef]

57. Apone, F.; Tito, A.; Carola, A.; Arciello, S.; Tortora, A.; Filippini, L.; Monoli, I.; Cucchiara, M.; Gibertoni, S.; Chrispeels, M.; et al. A mixture of peptides and sugars derived from plant cell walls increases plant defense responses to stress and attenuates ageing-associated molecular changes in cultured skin cells. J. Biotechnol. 2010, 145, 367-376. [CrossRef]

58. Ertani, A.; Pizzeghello, D.; Francioso, O.; Sambo, P.; Sanchez-Cortes, S.; Nardi, S. Capsicum chinensis L. growth and nutraceutical properties are enhanced by biostimulants in a long-term period: Chemical and metabolomic approaches. Front. Plant Sci. 2014, 5, 375. [CrossRef] 
59. Colla, G.; Rouphael, Y.; Canaguier, R.; Svecova, E.; Cardarelli, M. Biostimulant action of a plant-derived protein hydrolysate produced through enzymatic hydrolysis. Front. Plant Sci. 2014, 5, 448. [CrossRef]

60. Yasmeen, A.; Arif, M.; Hussain, N.; Naz, S.; Anwar, A. Economic analyses of sole and combined foliar application of moringa leaf extract (MLE) and $\mathrm{k}$ in growth and yield improvement of cotton. Int. J. Agric. Biol. 2018, 20, 857-863.

61. Lucini, L.; Rouphael, Y.; Cardarelli, M.; Bonini, P.; Baffi, C.; Colla, G. A vegetal biopolymer-based biostimulant promoted root growth in melon while triggering brassinosteroids and stress-related compounds. Front. Plant Sci. 2018, 9, 472. [CrossRef]

62. Ugolini, L.; Cinti, S.; Righetti, L.; Stefan, A.; Matteo, R.; D'Avino, L.; Lazzeri, L. Production of an Enzymatic Protein Hydrolyzate from Defatted Sunflower Seed Meal for Potential Application as a Plant Biostimulant. Ind. Crops Prod. 2015, 75, 15-23. [CrossRef]

63. Chon, S.U.; Nelson, C.J. Allelopathic dynamics in resource plants. In Allelopathy; Cheema, Z., Farooq, M., Wahid, A., Eds.; Springer: Berlin, Germany, 2012; pp. 81-110. [CrossRef]

64. Ghareib, H.R.A.; Abdelhamed, M.S.; Ibrahim, O.H. Antioxidative effects of the acetone fraction and vanillic acid from Chenopodium murale on tomato plants. Weed Biol. Manag. 2010, 10, 64-72. [CrossRef]

65. Hegab, M.M.; Khodary, S.E.A.; Hammouda, O.; Ghareib, H.R. Autotoxicity of chard and its allelopathic potentiality on germination and some metabolic activities associated with growth of wheat seedlings. Afr. J. Biotechnol. 2008, 7, 884-892.

66. Feng, J.; Wang, D.; Shao, C.; Zhang, L.; Tang, X. Effects of cold plasma treatment on alfalfa seed growth under simulated drought stress. Plasma Sci. Technol. 2018, 20, 035505. [CrossRef]

67. Pérez-Pizá, M.C.; Prevosto, L.; Zili, C.; Cejas, E.; Kelly, H.; Baleastrasse, K. Effects of non-thermal plasmas on seed-borne Diaporthe/Phomopsis complex and germination parameters of soybean seeds. Innov. Food Sci. Emerg. Technol. 2018, 49, 82-91. [CrossRef]

68. Strejckova, M.; Olsan, P.; Havelka, Z.; Bohata, A.; Kriz, P.; Bartos, P.; Curn, V.; Spatenka, P. Influence of physical and biological seed treatments on the yield of spring barley. Uroda 2016, 12, 45.

69. Hertwig, C.; Meneses, N.; Mathys, A. Cold atmospheric pressure plasma and low energy electron beam as alternative nonthermal decontamination technologies for dry food surfaces: A review. Trends Food Sci. Technol. 2018, 77, 131-142. [CrossRef]

70. Strejckova, M.; Bohata, A.; Olsan, P.; Havelka, Z.; Kriz, P.; Beran, P.; Bartos, P.; Curn, V.; Spatenka, P. Enhancement of the Yield of Crops by Plasma and Using of Entomopathogenic and Mycoparasitic Fungi: From Laboratory to Large-Field Experiments. J. Biomater. Tissue Eng. 2018, 8, 829-836. [CrossRef]

71. Adhikari, B.; Adhikari, M.; Ghimire, B.; Park, G.; Choi, E.H. Cold Atmospheric Plasma-Activated Water Irrigation Induces Defense Hormone and Gene expression in Tomato seedlings. Sci. Rep. 2019, 9, 16080. [CrossRef]

72. Ingels, R.; Graves, D.B. Improving the Efficiency of Organic Fertilizer and Nitrogen Use via Air Plasma and Distributed Renewable Energy. Plasma Med. 2015, 5, 257-270. [CrossRef]

73. Pérez-Pizá, M.C.; Grijalba, P.E.; Cejas, E.; Chamorro-Garcés, J.C.; Ferreyra, M.; Zilli, C.; Vallecorsa, P.; Santa-Cruz, D.; Yannarelli, G.; Prevosto, L.; et al. Effects of non-thermal plasma technology on Diaporthe longicolla cultures and mechanisms involved. Pest Manag. Sci. 2021, 77, 2068-2077. [CrossRef]

74. Pérez-Pizá, M.C.; Prevosto, L.; Grijalba, P.E.; Zilli, C.G.; Cejas, E.; Mancinelli, B.; Balestrasse, K.B. Improvement of growth and yield of soybean plants through the application of non-thermal plasmas to seeds with different health status. Heliyon 2019, 5, e01495. [CrossRef] [PubMed]

75. Pérez-Pizá, M.C.; Cejas, E.; Zilli, C.; Prevosto, L.; Mancinelli, B.; Santa-Cruz, D.; Yannarelli, G.; Balestrasse, K. Enhancement of soybean nodulation by seed treatment with non-thermal plasmas. Sci. Rep. 2020, 10, 4917. [CrossRef]

76. Pérez-Pizá, M.C.; Ibañez, V.N.; Varela, A.; Cejas, E.; Ferreyra, M.; Chamorro-Garces, J.C.; Vallecorsa, P.; Fina, B.; Prevosto, L.; Marfil, C.F.; et al. Non-Thermal Plasmas Affect Plant Growth and DNA Methylation Patterns in Glycine max. J. Plant Growth Regul. 2021, 1-11. [CrossRef]

77. Pérez-Pizá, M.C. Efecto del Tratamiento de Semillas de Soja con Plasma No-Térmico Sobre la Incidencia del Complejo Fúngico Diaporthe/Phomopsis. Unpublished. Doctoral Thesis, University of Buenos Aires, Buenos Aires, Argentina, 2020.

78. Vanraes, P.; Ghodbane, H.; Davister, D.; Wardenier, N.; Nikiforov, A.; Verheust, Y.P.; Swh, V.H.; Hamdaoui, O.; Vandamme, J.; Van, D.J. Removal of several pesticides in a falling water film DBD reactor with activated carbon textile: Energy efficiency. Water Res. 2017, 116, 1-12. [CrossRef] [PubMed]

79. Magureanu, M.; Mandache, N.B.; Parvulescu, V.I. Degradation of pharmaceutical compounds in water by non-thermal plasma treatment. Water Res. 2015, 81, 124-136. [CrossRef]

80. Ma, S.; Kim, K.; Huh, J.; Hong, Y. Characteristics of microdischarge plasma jet in water and its application to water purification by bacterial inactivation. Sep. Purif. Technol. 2017, 188, 147-154. [CrossRef]

81. Tanaka, H.; Nakamura, K.; Mizuno, M.; Ishikawa, K.; Takeda, K.; Kajiyama, H.; Utsumi, F.; Kikkawa, F.; Hori, M. Non-Thermal Atmospheric Pressure Plasma Activates Lactate in Ringer's Solution for Anti-Tumor Effects. Sci. Rep. 2016, 6, 36282. [CrossRef]

82. Boehm, D.; Heslin, C.; Cullen, P.J.; Bourke, P. Cytotoxic and mutagenic potential of solutions exposed to cold atmospheric plasma. Sci. Rep. 2016, 6, 21464. [CrossRef]

83. Merbahi, N.; Chauvin, J.; Vicendo, P.; Judee, F. Effects of plasma activated medium on head and neck FaDu cancerous cells: Comparison of 3D and 2D response. Anticancer Agents Med. Chem. 2017, 17, 776-783.

84. Zhang, Q.; Ma, R.; Tian, Y.; Su, B.; Wang, K.; Yu, S.; Zhang, J.; Fang, J. Sterilization Efficiency of a Novel Electrochemical Disinfectant against Staphylococcus aureus. Environ. Sci. Technol. 2016, 50, 3184-3192. [CrossRef] 
85. Shen, J.; Tian, Y.; Li, Y.; Ma, R.; Zhang, Q.; Zhang, J.; Fang, J. Bactericidal effect against S. aureus and physicochemical properties of plasma activated water stored at different temperatures. Sci. Rep. 2016, 6, 28505. [CrossRef] [PubMed]

86. Panngom, K.; Lee, S.H.; Park, D.H.; Sim, G.B.; Kim, Y.H.; Uhm, H.S.; Park, G.; Choi, E.H. Non-thermal plasma treatment diminishes fungal viability and up-regulates resistance genes in a plant host. PLoS ONE 2014, 9, e99300. [CrossRef]

87. Zhang, S.; Rousseau, A.; Dufour, T. Promoting lentil germination and stem growth by plasma activated tap water, demineralized water and liquid fertilizer. RSC Adv. 2017, 7, 31244-31251. [CrossRef]

88. Sivachandiran, L.; Khacef, A. Enhanced seed germination and plant growth by atmospheric pressure cold air plasma: Combined effect of seed and water treatment. RSC Adv. 2017, 7, 1822-1832. [CrossRef]

89. Lindsay, A.; Byrns, B.; King, W.; Andhvarapou, A.; Fields, J.; Knappe, D.; Fonteno, W.; Shannon, S. Fertilization of radishes, tomatoes, and marigolds using a large-volume atmospheric glow discharge. Plasma Chem. Plasma Process. 2014, 34, 1271-1290. [CrossRef]

90. Šimečková, J.; Krčma, F.; Klofáč, D.; Dostál, L.; Kozáková, Z. Influence of Plasma-Activated Water on Physical and PhysicalChemical Soil Properties. Water 2020, 12, 2357. [CrossRef] 